\title{
Comparative research of photosynthetic processes in selected poikilohydric organisms from Mediterranean and Central- European alpine habitats
}

\author{
Gabriella Nora Maria Giudici ${ }^{1}$, Josef Hájek ${ }^{2}$, Miloš Barták ${ }^{2}$, Svatava \\ Kubešová $^{3,4}$
}

${ }^{1}$ University of Naples Federico II, Department of Agriculture, 80055 Portici, Italy

${ }^{2}$ Masaryk University, Faculty of Science, Department of Experimental Biology, Laboratory of Photosynthetic Processes, Kamenice 5, Building A13, 62500 Brno, Czech Republic

${ }^{3}$ Masaryk University, Faculty of Science, Department of Botany and Zoology, Kamenice 5, 62500 Brno, Czech Republic

${ }^{4}$ Moravian Museum, Department of Botany, Hviezdoslavova 29a, 627 00, Brno, Czech Republic

\begin{abstract}
Dehydration-induced decrease in photosynthetic activity was investigated in five poikilohydric autotrophs using chlorophyll fluorescence parameters recorded during controlled desiccation. For the study, two representatives of mosses from alpine zone (Rhizomnium punctatum, Rhytidiadelphus squarrosus) of the Jeseníky Mts. (Czech Republic) were used. Other two experimental species were mediterranean habitats liverwort (Pellia endiviifolia) and moss (Palustriella commutata), collected from under Woodwardia radicans canopy in the Nature Reserve Valle delle Ferriere (Italy). The last species was a liverwort (Marchantia polymorpha) collected from lowland site (Brno, Moravia, Czech Republic). We investigated the relationship between relative water content (RWC) and several chlorophyll fluorescence parameters evaluating primary photochemical processes of photosynthesis, such as effective quantum yield of photosynthetic processes in photosystem II $\left(\Phi_{\mathrm{PSII}}\right)$, and non-photochemical quenching $(\mathrm{qN})$. With desiccation from fully wet $(\mathrm{RWC}=100 \%)$ to dry state $(\mathrm{RWC}=0 \%), \Phi_{\text {PSII }}$ exhibited a rapid ( $R$. punctatum) and slow decline of $\Phi_{\mathrm{PSII}}(R$. squarrosus, P. endiviifolia, $M$. polymorpha, and $P$. commutata). Shapes of dehydration-response curves were species-specific. $\mathrm{RWC}_{0.5}$, i.e. the $\mathrm{RWC}$ at which the sample showed half of maximum $\Phi_{\mathrm{PSII}}$, reflected the species-specificity. It reached $65 \%$ in desiccation sensitive ( $R$. punctatum), $53 \%$ and $43 \%$ in semi-tolerant ( $P$. commutata and $R$. squarrosus), $24 \%$ and $18 \%$ in desiccation-tolerant species ( $P$. endiviifolia and $M$. polymorpha). In all experimental species, non-photochemical quenching (qN) of absorbed light energy showed high values at $\mathrm{RWC}=100 \%$ and a slight increase with desiccation. Steady state chlorophyll fluorescence $\left(\mathrm{F}_{\mathrm{S}}\right)$ remained high during desiccation and was not correlated with $\Phi_{\mathrm{PSII}}$.
\end{abstract}

DOI: $10.5817 / \mathrm{CPR} 2018-2-24$

Received November 6, 2018, accepted December 22, 2018.

*Corresponding author: G. N. M. Giudici < gabriellanoramaria.giudici@unina.it>

Acknowledgements: The authors thank the projects CzechPolar-II (LM2015078) for providing Brno-based facilities and the infrastructure for the research reported in this study. The authors thank also for the support from ECOPOLARIS project (CZ.02.1.01/0.0/0.0/16 013/0001708) aimed to fund the research reported in this paper and Carabinieri per la biodiversità, UTB Caserta, for field support in collecting samples from Woodwardia radicans restricted area. The help of the members of the Extreme Environments Life (EEL) laboratory (Masaryk University, Department of Experimental Biology, Brno) provided during data processing is also acknowledged. 
Key words: chlorophyll fluorescence, moss, liverwort, dehydration, photosynthesis, Woodwardia radicans

\section{Introduction}

Mosses and liverworts, being desiccation tolerant poikilohydric autotrophs, cope well with dehydration/rehydration cycles and are capable to restore their photosynthetic activity soon after being rehydrated (Proctor et Smirnoff 2000). There are several ecophysiological adaptations, mainly protective mechanisms (see e.g. Greenwood 2017, for review), helping such organisms to inhibit and recover their photosynthetic activities during desiccation and rehydration, respectively. Most moss species are highly resistant to desiccation. The process of drying and rehydration can be repeated several times without causing major changes in the functioning of the organism (Stoklasa-Wojtasz et al. 2012). According to their capabilities to restore physiological characteristics after repeated cycles of hydration-dehydration, moss species are divided into two categories: desiccation tolerant or desiccation sensitive. This concept, however, is considered not generally valid recently since there are many interacting factors, such as e.g. phenotypic (Proctor et al. 2007) end ecotypic plasticity of the species, physiological 'history' of the sample, microclimate effects, the effects of the rate of desiccation/dehydration that may co-act and change the desiccation tolerance/sensitivity. Although many of protective mechanisms of bryophytes are common with the higher plants, there are fundamental interspecific differences in their response to desiccation. Study of Marschall et al. (2018) reported desiccation-tolerant (Porella platyphylla) and desiccation-sensitive (Sphagnum angustifolium) mosses. In slowly desiccating mosses, desiccation tolerance may increase thanks to the involvement of ABA (Mayaba et al. 2001, Wise et Tunnacliffe 2004). Early stages of moss desiccation are asso- ciated with an increase in thermotolerance, i.e. increase of thermal stability of chloroplastic photosynthetic apparatus, as shown for Homalothecium lutescens by Dulai et al. (2004). Recently, the phenomenon of inducible desiccation tolerance is studied in mosses. Generally, majority of mosses are considered desiccation-tolerant, while e.g. Marchantia polymorpha (liverwort) belongs to desiccation sensitive species (Nabe et al. 2007). Also Pellia endiviifolia is considered desiccation-intolerant liverwort species (Deltoro et al. 1998b). Since the 90-ies (e.g. Deltoro et al. 1998a, Csintalan et al. 1999) of the last century, chlorophyll fluorescence technique has been extensively used for the evaluation of dehydration effects on moss and liverwort photosynthesis. The approach was applied also in other poikilohydric organisms, such as e.g. Nostoc commune colonies (Barták et al. 2016). Typically, the photosynthetic studies of such autotrophs at different degrees of dehydration combine gas exchange and chlorophyll fluorescence measurements (e.g. $\mathrm{Hu}$ et al. 2016). Several previous studies (e.g. Heber et al. 2001, Pressel et al. 2006) have shown that chlorophyll fluorescence is almost totally suppressed during dehydration in bryophytes. Therefore, the change in chlorophyll fluorescence emission and chlorophyll fluorescence parameters is a very useful tool in the evaluation of negative effects of dehydration on moss/liverwort photosynthesis. It has been shown by e.g. Hájek et Beckett (2008) that critical relative water content (RWC) and/ or water potential of a moss thallus might be evaluated by chlorophyll fluorescence technique, the potential $\left(\mathrm{F}_{\mathrm{V}} / \mathrm{F}_{\mathrm{M}}\right)$ and effective quantum yield $\left(\Phi_{\mathrm{PSII}}\right)$.

In this comparative study, we focused on the changes in primary photosynthetic 
processes monitored by chlorophyll fluorescence parameters during desiccation in five poikilohydric autotrophs. We expected species-specific responses in gradually desiccating samples, among these the water content at which the first signs of inhibition of photosynthesis appear and the RWC

\section{Material and Methods}

\section{Sampling sites}

Samples of Rhizomnium punctatum and Rhytidiadelphus squarrosus were collected from the Jeseniky Mts. (NE of the Czech Republic, Moravian-Silesian region). The samples of $R$. punctatum were collected from the ground close to the margin of a stream with dominant grass cover close to the Barborka chalet (1 $320 \mathrm{~m}$ a.s.1.). Samples of $R$. squarrosus were collected from the locality called the Kapitánská stezka (940 $\mathrm{m}$ a.s.1.). The samples were collected from the moss-dominated vegetation covering a ground within a mature Norway spruce (Picea abies L.) stand (the Jeseníky Mts., Czech Republic). The climate of the Jeseníky Mts. is characterized by annual mean temperature of $1.1^{\circ} \mathrm{C}$ (from meteorological station Praděd, 1492 m a.s.l., Lednický 1985). The coldest month is January with the monthly mean of $-7.5^{\circ} \mathrm{C}$. The warmest one is July $\left(9.7^{\circ} \mathrm{C}\right)$. Annual sum of precipitation reaches $1231 \mathrm{~mm}$ with monthly maximum found in June $(180 \mathrm{~mm})$ and minimum in October $(69 \mathrm{~mm})$. The samples of Marchantia polymorpha were collected from moist soil surface in ornamental flower gardens (Brno, South Moravia, Czech Republic) located close to the Svratka river. Mean annual air temperature is $9.1^{\circ} \mathrm{C}$, mean annual precipitation is $490 \mathrm{~mm}$ (meteorological station BrnoTuřany, Dobrovolný et al. 2012). The samples were delivered to the laboratories, during the autumn 2018, then dried and stored for 3 weeks until the beginning of experiments. at which a half of the maximum $\Phi_{\mathrm{PSII}}$ is found. The emphasis was also given to the critical RWC, i.e. relative water content at which the individual species show full limitation of primary photochemical processes of photosynthesis.

Samples of Pellia endiviifolia and $\mathrm{Pa}$ lustriella commutata were collected in the Valle delle Ferriere (Italy), $33 \mathrm{~km} \mathrm{SE}$ of Naples and $17 \mathrm{~km}$ west of Salerno. The locality is a deep valley rich in water and waterfalls, with a permanent stream at its bottom (Canneto). The area is located in the southern side of the Sorrento peninsula, made by Mesozoic limestone, transgressive Miocene calcarenite and flysch, with occurrences of volcanic deposits from Somma-Vesuvius. The main valley is crossed by secondary valleys and the underground faults along with the karst system regulate the water flow and drainage, generating many springs. It is surrounded by mountains and peaks, the altitude of which ranges from 300 to $1203 \mathrm{~m}$ a.s.l. The climate is warm temperate $\left(20^{\circ} \mathrm{C}\right.$ to $5^{\circ} \mathrm{C}$ ). The average annual rainfall of 1500 (mountain) to 1000 (sea level) $\mathrm{mm}$, hits its maximum in the autumn - winter period. The proximity of the mountains to the coast is the cause of the high rainfall and mists because of condensation of humid air masses brought from the sea by wind. The particular orography creates very different microclimates and altitude plant distribution shows thermal inversion, i.e. mesophyll woods are at the bottom of the valleys and Mediterranean vegetation is on higher slopes and mountain ridges. Because of these very particular microclimatic conditions, the valley is home to many different vegetal and animal species listed in EU Red List, e.g. Woodwardia radicans 
and Pteris cretica, both tropical relicts. Three of its seven EU enlisted habitats are priority habitat types including "Petrifying springs with tufa formation", hard water springs with active formation of travertine or tufa, on the rocky walls and forest, dominated by bryophyte vegetation (Cratoneurion commutati).

\section{Species characteristics}

The above-specified experimental species were determined and the nomenclature of the species follows Hill et al. (2006).

\section{Pellia endiviifolia}

$P$. endiviifolia is a thallose liverwort with green or blackish-green thalli up to about $1 \mathrm{~cm}$ wide, without reddish tinges. Narrow (6 mm wide) and numerous new branches are developed at their tips in autumn or early winter. Pellia is dioicous

\section{Marchantia polymorpha}

M. polymorpha is a thallose liverwort which typically forms flattened thalli. Thalli of the liverwort are green, pale green on the ventral side. They are usually sized 4$6 \mathrm{~cm}$ even or sometimes up to $15 \mathrm{~cm}$ long and about $1-2 \mathrm{~cm}$ wide. The thalli are dichotomously branched. Thallus margins could be slightly uplifted, gently sliced, sometimes with a blurred, black stripe in the middle. The middle rib located at the

\section{Rhizomnium punctatum}

$R$. punctatum is a moss species common to wet places in forests. It is mediumsized moss forming rather loose tufts of dark green color, about $1-10 \mathrm{~cm}$ high. The cauloid is typically red or brown, with noticeable rhizoids at the bottom. The leaves (phyloids) are thin, round to broadly oblique, with a rounded toe. The species has oval- or egg-shaped leaves that are usually broader above the middle. When dry, the with the female organ protected by a vertical tooth-mouthed tube. $P$. endiviifolia occurs in base-rich sites, is found by watercourses, springs, shaded moist underwood, fens and dune slacks, dripping rock outcrops (Atherton et al. 2010).

bottom is not very distinct from the basic tissue. Clear breathing holes sized 60-100 $\times 40-80 \mu \mathrm{m}$ can be distinguished on upper surface. Thalli bear scattered, cup-shaped gemma receptacles. $M$. polymorpha grows on rocks, stones in/beside streams, in springs, beside reservoirs and in manmade habitats in gardens, on footpaths, on walls, and on old bonfire sites (Atherton et al. 2010).

leaves are contorted and twisted. The edge of the entire petal is lined with a number of prosenchymatic cells. The rib ends at the tip, or is rarely a little truncated. In the Czech Republic, $R$. punctatum is a very common species growing in damp, shaded places. It grows on the ground, rocks, rotting wood, especially along the streams, from the lowlands to the mountains. 
Rhytidiadelphus squarrosus

$R$. squarrosus is a strong, green to yellowish-green moss species forming usually dense carpets. The shoots of this extremely common moss are about 10-15 cm long, sometimes branched, and distinctive in the way the tapered part of the $2-2.5 \mathrm{~mm}$ long leaves bend back at a right angle to the base so that they spread out and away from the stem in all directions, giving shoots a star-like appearance. The stem leaves are straight, ovate to broadly ovate, and tapered

\section{Palustriella commutata}

Shoots of $P$. commutata are typically green or yellowish-brown, 4-6 cm long or more, with a densely and regularly pinnate pattern of branching. This type of branching looks rather feather-like, but calcareous deposits on the shoots make them feel stiff and rough. The stem is covered by tiny leaf-like structures and red-brown rhizoids. The species has triangularly heart- in the long, narrow to truncated tip, thinly edged. The broad leaf base completely sheathes the red stem. The leaf has lightly toothed margins and a short double nerve. $R$. squarrosus is a ubiquitous species growing in open and shady habitats. It is common in unimproved or semi-improved grasslands. It tolerates a wide variety of soil conditions, from calcareous grassland to acid heaths.

shaped leaves that are 2-2.5 $\mathrm{mm}$ long, pleated, and have a very stout nerve that extends to the long, fine tip. $P$. commutata occurs in a variety of wet, base-rich habitats. The species is particularly characteristic of wet cliffs, springs and flushes. It often forms extensive patches, and may drape dripping, calcareous cliffs (Atherton et al. 2010).

\section{Chlorophyll fluorescence in response to dehydration}

Measurements of chlorophyll fluorescence parameters were done in samples desiccating from fully hydrated to fully dry state in laboratory. During the desiccation, room temperature was kept constant $\left(23^{\circ} \mathrm{C}, 40 \% \mathrm{RH}\right)$ and bryophyte thalli were left in open Petri dishes to desiccate naturally. Before the experiments, and repeatedly during the sample desiccation, relative water content (RWC) was evaluated using a gravimetric method. Samples were weighted on an analytical Mettler scale (Mettler AS100, Germany), and RWC calculated according to the equation 1 :

$\operatorname{RWC}(\%)=\left[\left(\mathrm{F}_{\mathrm{M}}-\mathrm{D}_{\mathrm{M}}\right) /\left(\mathrm{F}_{\mathrm{W}}-\mathrm{D}_{\mathrm{M}}\right)\right] * 100$

where, $F_{M}$ is the actual fresh mass (weight) of a sample during the measurements, $D_{M}$ is the mass of fully dry sample, and
$\mathrm{F}_{\mathrm{W}}$ is the mass of fully wet sample. From fully wet $(\mathrm{RWC}=100 \%)$ to dry $(\mathrm{RWC}=$ $0-10 \%$ ) state of the moss/liverwort thalli, chlorophyll fluorescence parameters were measured repeatedly. They comprised (1) effective quantum yield $\left(\Phi_{\mathrm{PSII}}\right)$ of photosystem II, (2) non-photochemical quenching ( $\mathrm{qN})$, and (3) steady state chlorophyll fluorescence $\mathrm{F}_{\mathrm{S}}$ (for parameters definition and equations see Roháček et Barták 1999).

For chlorophyll fluorescence measurements, a PAM-2000 fluorometer (H. Walz, Germany) with a custom-programmed measuring routine was used. Saturation pulses were applied on the samples at light-acclimated state (exposed to $20 \mu \mathrm{mol}$ $\mathrm{m}^{-2} \mathrm{~s}^{-1}$ of PAR) at $10 \mathrm{~min}$. intervals. Since the chlorophyll fluorescence measurements were taken simultaneously with RWC evaluation, the dehydration-response curves of 
$\Phi_{\text {PSII }}, \mathrm{qN}$, and $\mathrm{F}_{\mathrm{S}}$ could be plotted (see Figs. 1 and 2) and analyzed. Species-specific responses in the dehydration-induced de- cline in photosynthetic parameters were pointed out and RWCs at which the functional changes happened were evaluated.

\section{Results and Discussion}

The chlorophyll fluorescence data recorded during dehydration from fully wet $(\mathrm{RWC}=100 \%)$ to dry state $(\mathrm{RWC}=0 \%)$ revealed species-specific response of chlo- rophyll fluorescence level measured at steady state $\left(F_{S}\right)$, effective quantum yield of photosystem II $\left(\Phi_{\text {PSII }}\right)$, and non-photochemical quenching (qN).

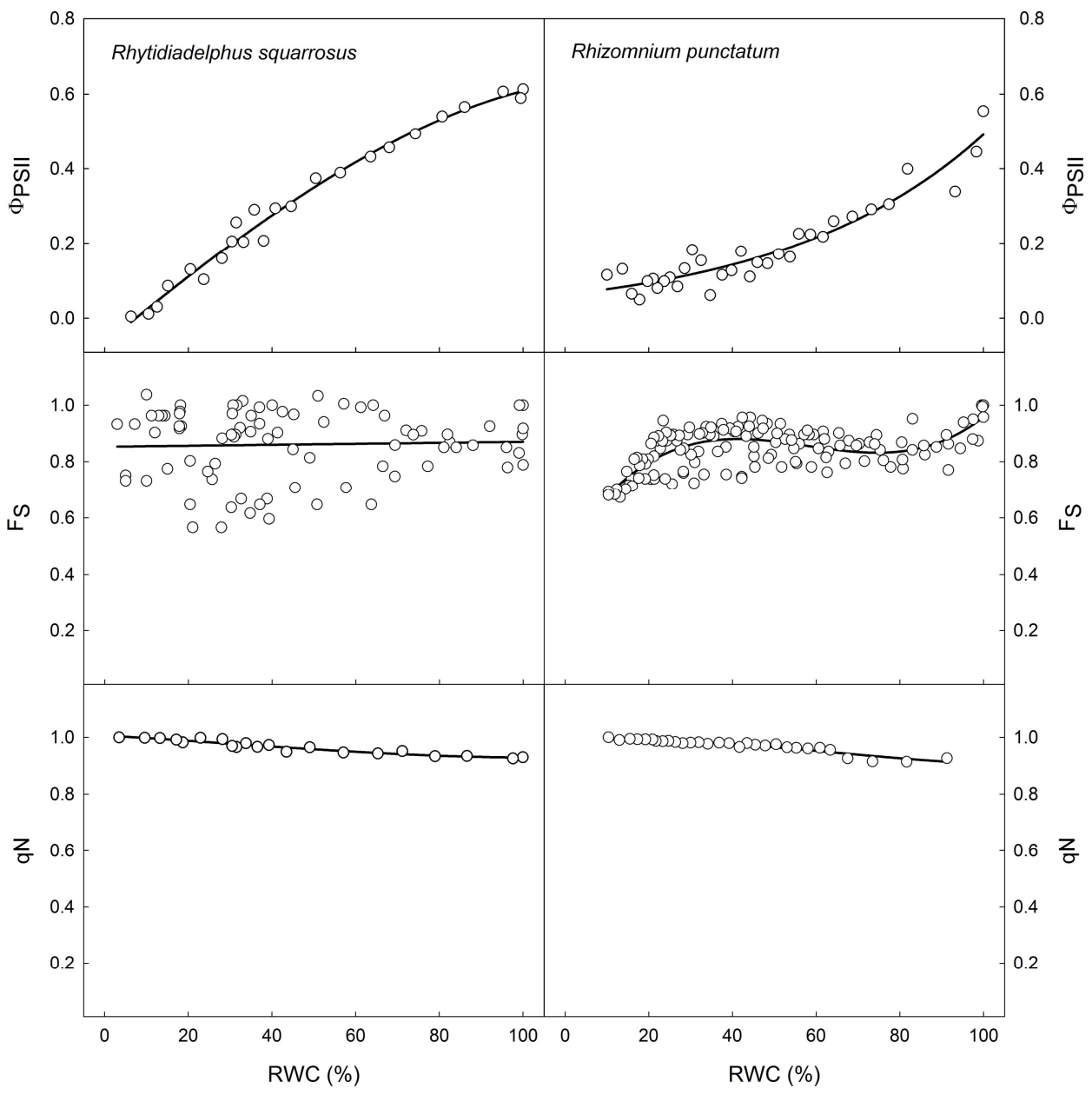

Fig. 1. Dehydration response curves of chlorophyll fluorescence parameters: effective quantum yield of photosynthetic processes in PS II $\left(\Phi_{\mathrm{PSII}}\right)$, non-photochemical quenching ( $\mathrm{qN}$ - normalized to maximum value), and steady-state chlorophyll fluorescence $\left(\mathrm{F}_{\mathrm{S}}\right)$ in Rhytidiadelphus squarrosus (left) and Rhizomnium punctatum (right). Key to the abbreviations: RWC - relative water content. 
Dehydration-response curves of $\Phi_{\text {PSII }}$ had, apart from $R$. punctatum, typical biphasic character with 2 main phases that differed between the studied species (Figs. $1,2)$. At the RWC ranges decreasing from 100 to $80 \%$ (R. squarrosus, $P$. commutata), 100 to $70 \%$ ( $P$. endiviifolia), and 100 to $60 \%$ (M. polymorpha), $\Phi_{\text {PSII }}$ decreased in a slow rate. With gradual dehydration from RWC of $60 / 70 / 80$ to $0 \%$, a rapid decline appeared in the four species following an S-curve. At RWC of 5\% (P. endiviifolia, $R$. squarrosus, $M$. polymorpha) and $15 \%$ (P. commutata), critical point for photosynthetic processes $\left(\Phi_{\mathrm{PSII}}=0\right)$ was found. In $P$. endiviifolia, the second phases of the response curves were similar in shape to those reported by Nabe et al. (2007) with a typical S-curve at low RWCs.

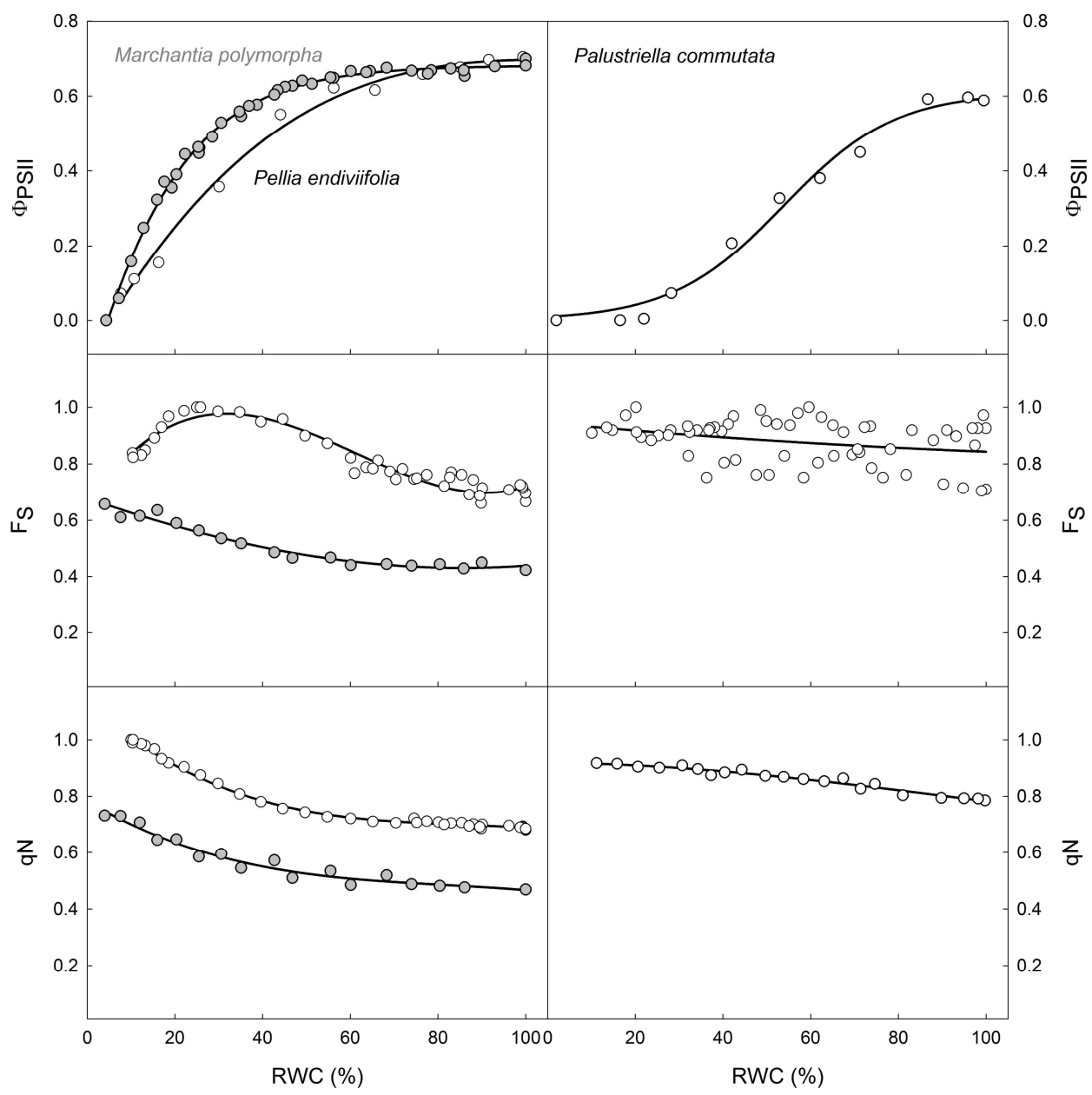

Fig. 2. Dehydration response curves of chlorophyll fluorescence parameters: effective quantum yield of photosynthetic processes in PS II $\left(\Phi_{\mathrm{PSII}}\right)$, non-photochemical quenching ( $\mathrm{qN}$ - normalized to maximum value), and steady-state chlorophyll fluorescence ( $F_{S}$ - normalized to maximum value) in Pellia endiviifolia and Marchantia polymorpha (left) and Palustriella commutata (right). Key to the abbreviations: RWC - relative water content. 
Among the studied species, $R$. punctatum exhibited different desiccation-response curve: $\Phi_{\text {PSII }}$ declined in an exponential manner showing the fastest decline within $70-100 \%$ RWC and 0 point at 8.2 RWC.

Half of $\Phi_{\text {PSII }}$ was reached at high level of RWC by $R$. punctatum (65\%), medium RWC by $P$. communtata and $R$. squarrosus (53 and $43 \%$ ), low RWC by $M$. polymorpha (18\%). These data confirm that tolerance to desiccation is high or medium for the five species except $R$. punctatum. The data show that primary photosynthetic processes in photosystem II are still active even at severe desiccation, which may have consequences for the species functioning under adverse environment conditions (e.g. high water demand). Being the four species able to cope with severe dehydration at the level of primary photosynthetic processes, further investigations should clarify the particular co-action of high light and temperature during desiccation.

Our experimental species proved, except $R$. punctatum, to be desiccation tolerant or semitolerant, since the majority of down regulation of primary photochemical processes, i.e. rapid decline of $\Phi_{\mathrm{PSII}}$ and increase in qN were found at the RWC below $70 \%$. This is comparable to a large number of moss species, however, some mosses are reported to be desiccation intolerant (e.g. Sphagnum - Marchall et Borbely 2011). In our study, $P$. endiviifolia and $M$. polymorpha were found tolerant, because the rapid decline in $\Phi_{\text {PSII }}$ appeared at about $50-60 \%$ RWC. These findings do not agree with Nabe et al. (2007) who ranks $M$. polymorpha among desiccation sensitive bryophytes. On the other hand Hatanaka et Sugawara (2010) report high desiccation tolerance of $M$. polymorpha suspension-cell culture which is consistent with our data (see Fig. 2). In tolerant lichens, the RWC in which the decline is apparent, is even lower, i.e. 30-40\% (Barták et al. 2018). Since all the studied species showed slow but permanent increase in $\mathrm{qN}$ with the RWCs decline from 100 to $0 \%$, it might be suggested that the protective mechanisms involved in non-photochemical quenching were activated throughout desiccation. For mosses and liverworts, the functional background of desiccation-induced quenching is still not well understood. The desiccation-tolerant bryophytes are characterized by the fact that they do not suffer from photooxidative damage due to the coexistence of zeaxantin-dependent and dehydration-induced thermal energy dissipation (Marschall et al. 2018). Quenching due to the interconversion of xanthophyll cycle pigments was reported in bryophytes during desiccation under light conditions (Deltoro et al. 1998b, Nabe et al. 2007). Additionally, Heber et Shuvalov (2005) suggested that reaction centre of PS II (P680) might be converted into $\mathrm{Chl}_{720}$ which is effective in quenching. More recently, two mechanism were proposed by Heber (2012). One of them facilitates energy dissipation in the antenna of photosystem II which is faster than energy capture by functional reaction centres. When this mechanism is insufficient for full photoprotection, the other one permits energy dissipation in the reaction centres themselves. The latter mechanism is based on the involvement of an efficient spillover, i.e. energy transfer from PS II to PS I as suggested by (Slavov et al. 2013). The phenomenon is named desiccation-induced quenching and was described as a property of photosystem II reaction centres in $R$. squarrosus (Heber et al. 2006). The authors found that during desiccation, quenchers accumulate and are stable in the absence of water but revert to non-quenching molecular species on hydration. Together with zeaxanthin-dependent energy dissipation, desiccation-induced thermal energy dissipation protects desiccated poikilohydric mosses against photo-oxidation, ensuring survival during drought periods. This mechanism requires light but not formation of transthylakoidal delta $\mathrm{pH}$ (proton) gradient. The follow-up study done on the same species (Yamakawa et al. 2018) re- 

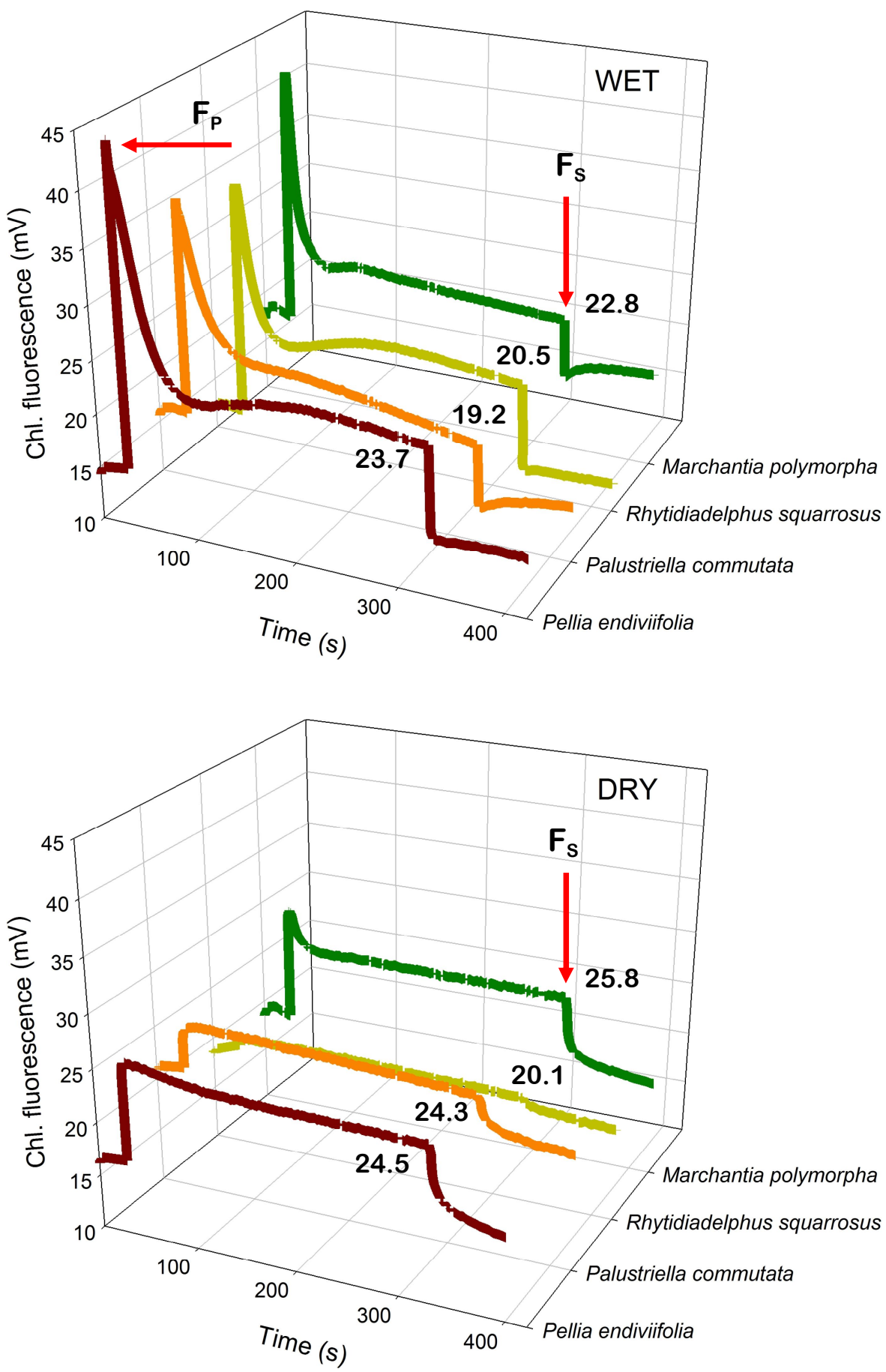

Fig. 3. Record of slow Kautsky kinetics for selected experimental species in wet ( $90 \%$ RWC) and dry state $\left(10 \%\right.$ RWC). Note that, irrespective of species, $F_{S}$ are almost the same value in wet and dry state. Desiccation leads to diminishing of P peak (indicated by an arrow). 
vealed that the quenching did not fully accelerated the PS II decay. The authors tentatively denoted this as type-B quenching. The desiccation-induced quenching in mosses is in strong contrast to the lightinduced non-photochemical quenching as seen in higher plants affected by photoinhibitory light doses (Bilger 2014).

Complex character of protection of photosynthetic apparatus in desiccating mosses is documented by Yamakawa et al. (2012) in desiccation-tolerant moss Rhytidium rugosum. The authors report three different types of non-photochemical de-excitation of absorbed light energy and conclude that the slow drying moss (under light) has a better photo-protection than the same one slowly drying in darkness. Antioxidative substrates and enzymes might be involved into quenching as well since they represent effective agents acting against the ROS formed during desiccation. Paciolla et Tommasi (2003) studied ascorbate contents in wet and dry Brachytheciastrum velutinum (syn. Brachythecium velutinum) and Marchantia polymorpha. They report more efficient ascorbate recycling in the moss than in the liverwort, and suggest higher desiccation tolerance in the moss than the liverwort. Recently, an abcisic acid-independent cold signalling pathway was found in Marchantia polymorpha that leads to

\section{Concluding remarks}

The research reported in this study was carried out at the Jeseníky mountains (Czech Republic) and in the Valle delle Ferriere (Italy). The Jeseníky Mts. are under strict natural protection and comprise preserved nature of the highest peaks having the character of the northern tundra similar to that found in the Alps and Polar regions. The natural treeless landscape above the upper border of the forest at an altitude of $1350 \mathrm{~m}$ has a bare and rocky Alpine character. The other location, the specific gene expression that is related to freezing and desiccation tolerance (Minami et al. 2005). However, the extent of involvement of such mechanism during desiccation and the co-action with photosynthetic performance remain unclear.

Steady-state chlorophyll fluorescence $\left(F_{S}\right)$ did not show rapid decline with progressive desiccation. The response of $F_{S}$ was species-specific: It slightly decreased (R. punctatum), stayed more or less constant ( $R$. squarrosus), slightly increased ( $P$. commutata), and showed an increase followed by a decrease ( $P$. endiviifolia). Similarly, Bartošková et al. (1999) reported almost constant $\mathrm{F}_{\mathrm{P}}$ chlorophyll fluorescence signal in desiccating in $R$. punctatum. Generally, the responses were different from lichens that show a rapid $F_{S}$ decline with RWC decrease from 100 to $0 \%$. The response of $F_{P}$, however, seems to be species-specific. Tuba et al. (1996) reported big differences in $\mathrm{F}_{\mathrm{P}}$ during desiccation in Tortula ruralis. Therefore, in follow-up studies, attention will be payed to the changes in $F_{P}$ and $F_{S}$ in moss species during desiccation. Mosses and liverwort exhibited more or less constant Fs within a wide range of RWC as documented from slow Kautsky kinetics (see values in wet and dry state, Fig. 3).

Valle delle Ferriere, is a unique landscape of high natural biodiversity and historical value; the valley is included in many protected areas lists: Nature reserve 1972 (DM 427 29/03/1972), part of the Regional Park Monti Lattari (LR 33 01/09/1993), SPA (Sorgenti del Vallone delle Ferriere di Amalfi ) IT8050045, SCI (dorsale dei Monti Lattari) IT8030008, UNESCO site Costiera Amalfitana IT 830 inscription 1997. 


\section{References}

Atherton, I., Bosanquet, S. and Lawley, M. (Eds.) (2010): Mosses and liverworts of Britain and Ireland - a field guide. British Bryological Society, Plymouth, $848 \mathrm{p}$.

Barták, M., Hazdrová, J., SkÁcelová, K. and HáJek, J. (2016): Dehydration-induced responses of primary photosynthetic processes and spectral reflectance indices in Antarctic Nostoc commune. Czech Polar Reports, 6: 87-95.

BARTÁk, M., HáJeK, J., MorkusovÁ, J., SkÁcelovÁ, K. and KošuthovÁ, A. (2018): Dehydrationinduced changes in spectral reflectance indices and chlorophyll fluorescence of Antarctic lichens with different thallus color, and intrathalline photobiont. Acta Physiologiae Plantarum, 40: 177-187.

BARToŠKovÁ, H., KomendA, J. and NAUŠ, J. (1999): Functional changes of photosystem II in the moss Rhizomnium punctatum (Hedw.) induced by different rates of dark desiccation. Journal of Plant Physiology, 154: 597-604.

BiLgeR, W. (2014): Desiccation-Induced Quenching of Chlorophyll Fluorescence in Cryptogams. In: B. Demmig-Adams, G. Garab, W.W.Adams III, and Govindjee (Eds.): Non-photochemical quenching and energy dissipation in plants, algae and cyanobacteria. Springer Dordrecht, New York, Tokyo, Heidelberg, New York, pp. 409-420.

Csintalan, Z., Proctor, M. C. F. and Tuba, Z. (1999): Chlorophyll fluorescence during drying and rehydration in the mosses Rhytidiadelphus loreus (Hedw.) Warnst., Anomodon viticulosus (Hedw.) Hook. and Tayl. and Grimmia pulvinata (Hedw.) Sm. Annals of Botany, 84: 235-244.

Deltoro, V. I., Calatayud, A., Gimeno, C. and Barreno, E. (1998a): Water relations, chlorophyll fluorescence, and membrane permeability during desiccation in bryophytes from xeric, mesic, and hydric environments. Canadian Journal of Botany, 76: 1923-1929.

Deltoro, V. I., Calatayud, A., Gimeno, C., Abadía, A. and Barreno, E. (1998b): Changes in chlorophyll a fluorescence, photosynthetic $\mathrm{CO}_{2}$ assimilation and xanthophyll cycle interconversions during dehydration in desiccation-tolerant and intolerant liverworts. Planta, 207: 224-228.

Dobrovolný, P., ŘezníčKová, L., Brázdil, R., Krahula, L., Zahradníček, P., Hradil, M., Doleželová, M., ŠÁlek, M., ŠtěPÁnek, P., RožnovskÝ, J., Valášek, H., KirChNer, K. and KolejKA, J. (2012): Klima Brna. Víceúrovňová analýza městského klimatu. 1. vyd. Brno: Masarykova univerzita, 200 p. ISBN 978-80-210-6029-6. (In Czech).

Dulai, S., Csizi, K., SAss-Gyarmati, A., OrbÁn, S. and MolnÁr, I. (2004): Combined effects of Thylakoid Energisation Level and Water Deficit on Thermal Stability of Photosystem II in a Dessication Tolerant Moss. Acta Academiae Paedagogicae Agriensis, Sectio Biologiae, XXV: 127-126.

GREENWOOD, G. L. (2017): Factors influencing induction of desiccation tolerance in bryophytes: redefining fundamental aspects of the organism's relationship with the environment in xeric habitats. Ph.D. thesis, University of Nevada, Las Vegas, $118 \mathrm{p}$.

HÁJEK, T., BECKETT, R. P. (2008): Effect of water content components on desiccation and recovery in Sphagnum mosses. Annals of Botany, 101: 165-173.

HatanaKa, R., Sugawara, Y. (2010): Development of desiccation tolerance and vitrification by preculture treatment in suspension-cultured cells of the liverwort Marchantia polymorpha. Planta, 231: 965-976.

Heber, U., Bukhov, N. G., Shuvalov, V. A., Kobayashi, Y. and Lange, O. L. (2001): Protection of the photosynthetic apparatus against damage by excessive illumination in homoiohydric leaves and poikilohydric mosses and lichens. Journal of Experimental Botany, 52: 1999-2006.

Heber, U., Shuvalov, V. A. (2005): Photochemical reactions of chlorophyll in dehydrated photosystem II: two chlorophyll forms (680 and $700 \mathrm{~nm}$ ). Photosynthesis Research, 84: 85-91.

Heber, U., Bilger, W. and Shuvalov, V. A. (2006): Thermal energy dissipation in reaction centres and in the antenna of photosystem II protects desiccated poikilohydric mosses against photo-oxidation. Journal of Experimental Botany, 57: 2993-3006.

HeBer, U. (2012): Conservation and dissipation of light energy in desiccation-tolerant photoautotrophs, two sides of the same coin. Photosynthesis Research, 113: 5-13. 
Hill, M. O., Bell, N., Bruggeman-Nannenga, M. A., Brugués, M., Cano, M. J., Enroth, J., Flatberg, K. I., Frahm, J.-P., Gallego, M. T., Garilleti, R., Guerra, J., Hedenäs, L., Holyoak, D. T., Hyvönen, J., Ignatov, M. S., Lara, F., Mazimpaka, V., Muñoz, J. and GUERRA, J. (2006): An annotated checklist of the mosses of Europe and Macaronesia. Journal of Bryology, 28: 198-267.

Hu, R., XIAO, L., BAO, F., LI, X. and He, Y. (2016): Dehydration-responsive features of Atrichum undulatum. Journal of Plant Research, 129: 945-954. doi: 10.1007/s10265-016-0836-x.

LeDNiCKÝ, V. (1985): Climate the Praděd Mt. Šumperk, Severní Morava, 49: 44-48. (In Czech).

Marschall, M., Borbély, P. (2011): Photosynthetic responses of the desiccation intolerant Sphagnum angustifolium in relation to increasing its desiccation tolerance by exogenous ABA. Acta Biologica Szegediensis, 55: 119-121. Available: https://www2.sci.u-szeged.hu/ABS/2011/ Acta\%20HP/55119.pdf.

Marschall, M., BorbÉly, P., PNÉ-KÓNYA, E. and SÜTO, S. (2018): Background processes and the components of photoprotection and regeneration under rehydration in desiccation-tolerant and desiccation-sensitive bryophytes. In: Abstract Book for the Plant Biology Europe Conference in Copenhagen, 80 p. (ISBN 978-87-996274-1-7).

Mayaba, N., Beckett, R. P., Csintalan, Z. and Tuba, Z. (2001): ABA increases the desiccation tolerance of photosynthesis in the afromontane understorey moss Atrichum androgynum. Annals of Botany, 88: 1093-1100.

Minami, A., Nagao, M., Ikegami, K., Koshiba, T., Arakawa, K., Fujikawa, S. and Takezawa, D. (2005): Cold acclimation in bryophytes: Low-temperature-induced freezing tolerance in Physcomitrella patens is associated with increases in expression levels of stress-related genes but not with increase in level of endogenous abscisic acid. Planta, 220: 414-423

Nabe, H., Funabiki, R., Kashino, Y., Koike, H. and SAtoh, K. (2007): Responses to desiccation stress in bryophytes and an important role of dithiothreitol-insensitive non-photochemical quenching against photoinhibition in dehydrated states. Plant and Cell Physiology, 48: 15481557.

Paciolla, M., Tommasi, F. (2003): The ascorbate system in two bryophytes: Brachythecium velutinum and Marchantia polymorpha. Biologia Plantarum, 47: 387-393.

Pressel, S., Ligrone, R. and Duckett, J. G. (2006): The effects of de- and rehydration on foodconducting cells in the moss Polytrichum formosum Hedw: A cytological study. Annals of Botany, 98: 67-76.

Proctor, M. C. F., SMirnoff, N. (2000): Rapid recovery of photosystems on rewetting desiccation - tolerant mosses: chlorophyll fluorescence and inhibitor experiments. Journal of Experimental Botany, 51: 1695-1704. Available: https://doi.org/10.1093/jexbot/51.351.1695.

Proctor, M. C. F., Oliver, M. J., Wood, A. J., Alpert, P., Stark, L. R., Cleavitt, N. L. and MishleR, B. D. (2007): Desiccation-tolerance in bryophytes: a review. The Bryologist, 110: 595-622.

RoHÁČEK, K., BARTÁK, M. (1999): Technique of the modulated chlorophyll fluorescence: Basic concepts, useful parameters, and some applications. Photosynthetica, 37(3): 339-363.

Slavov, Ch., Reus, M. and Holzwarth, A. R. (2013): Two different mechanisms cooperate in the desiccation-induced excited state quenching in Parmelia lichen. The Journal of Physical Chemistry B, 117 (38): 11326-11336.

Stoklasa-Wojtasz, A., Rzepka, A. and Rit, G. (2012): Responses of mosses species on environment stress factors. In: M. T. Grzesiak, A. Rzepka, T. Hura, S. Grzesiak (Eds.): Plant functioning under environmental stress. The F. Górski Institute of Plant Physiology, Polish Academy of Science, Cracow, Poland, pp. 69-83.

Tuba, Z., Csintalan, Z. and Proctor, M. C. F. (1996): Photosynthetic responses of a moss, Tortula ruralis ssp. ruralis, and the lichens Cladonia convoluta and C. furcata to water deficit and short periods of desiccation, and their ecophysiological significance: A baseline study at present-day concentration. New Phytologist, 133: 353-361.

Wise, M.J., TunNAClifFe. A. (2004): POPP the question: What do LEA proteins do? Trends in Plant Science, 9: 13-17. 
Yamakawa, H., Fukushima, Y., Itoh, S. and Heber, U. (2012): Three different mechanisms of energy dissipation of a desiccation-tolerant moss serve one common purpose: to protect reaction centres against photo-oxidation. Journal of Experimental Botany, 63: 3765-3775.

YAmAKAwa, H., van StoKkuM, I. H. M., Heber, U. and ITOH, S. (2018): Mechanisms of droughtinduced dissipation of excitation energy in sun- and shade-adapted drought-tolerant mosses studied by fluorescence yield change and global and target analysis of fluorescence decay kinetics. Photosynthesis Research, 135: 285-298. 